155 RUNA JOHANNESSEN

Adjunkt

Institut for Bygningskunst og Teknologi, Det Kongelige Akademi

ISAK WINKEL HOLM

Professor

Institut for Kunst- og Kulturvidenskab, Københavns Universitet

\title{
VI BYGGER FOR LIVET
}

\section{Medikalisering af den danske hospitalsarkitektur}

I 1913 indviede Københavns Kommune sit nye hospital på Bispebjerg. Placeringen af hospitalet på en sydøstvendt bakke uden for Københavns larm og røg sørgede for optimale rammer for hospitalsanlægget, der var tegnet af arkitekten Martin Nyrop (1849-1921) og landskabsarkitekten Edvard Glæsel (1858-1915). På anbefaling fra hospitalskommissionen, som var nedsat for at rådgive politikerne om byggeriet, skulle hospitalet opføres som lave pavilloner omgivet af haver. Haverne skulle fungere som forlængelser af sygestuerne, uanset om man selv kunne gå ud og sætte sig på bænkene, om man blev båret ud i sin seng af portørerne, eller om man kiggede ud på det grønne gennem de store vinduer fra sit leje i de sydvendte sygestuer. Kommissionen begrundede valget af pavillonhospitalet som bygningstype således: "Ikke mindst i vort forholdsvis solfattige Klima er det af Betydning at kunne placere Hospitalsbygninger paa en saadan Maade, at der til Sygestuerne skaffes den bedste Adgang for Luft og Lys ... " (Hansen og Permin). Antibiotika blev først udviklet i 1943, så i manglen af en egentlig medicinsk behandling foreskrev datidens læger adgang til sollys, frisk luft og grønne omgivelser som immunstyrkende terapi, og kommissionens tanke var, at hospitalets rumlige udformning 
156 KULTUR \& KLASSE *131*2021 SYGDOM

skulle fungere som et remedie: som et arkitektonisk redskab, der kunne bidrage til helbredelsen af patienterne.

I dag er Region Hovedstaden i fuld gang med en omfattende udvidelse og renovering af det gamle hospital i projekt Nyt Hospital Bispebjerg. Ud over planlægningen af supplerende hospitalsbygninger blev der i 2015 udarbejdet en visions- og helhedsplan for hele området med titlen Gardens of Life (Polyform Arkitekter). Som en del af projektet blev der indbudt til en arkitektkonkurrence om reetablering af hospitalets gamle og fredede haveanlæg, og med vinderforslaget skal Glæsels gamle have nu "genfødes" i form af en såkaldt "helende have" med seks mindre temahaver som f.eks. Barselshaven, Den Muskuloskeletale Have (til fysioterapien) og Det Udendørs Venteværelse (Nyt Hospital Bispebjerg). Det skal blive nemmere for både oppegående og sengeliggende patienter at komme ud i haven for at få luft, lys og sanseindtryk i mødet med blomster og træer.

Det er ikke svært at få øje på lighederne i opfattelsen af forholdet mellem hospitalsarkitektur og helbredelse i det nye og det gamle Bispebjerg Hospital. Denne lighed hviler først og fremmest på en medikalisering af arkitekturen, og det vil sige på en anvendelse af hospitalets fysiske miljø som remedie for helbredelse. Både i 1913 og i 2021 er det ikke mindst haverne, der bliver opfattet som afgørende for hospitalets terapeutiske funktion. I jubilæumsbogen Bispebjerg Hospital 100 år (2013) skriver Peter Wagner og Henrik Permin eksempelvis, at det næppe kun er af ærbødighed over for arkitekturen, at hospitalets oprindelige bygninger nu er blevet fredet:

Tidligere tiders viden og erfaring om gode og smukke omgivelsers positive effekt for behandling af sygdomme i almindelighed er blevet genopdaget og for nylig i dansk sammenhæng beskrevet i Sansernes Hospital og i undersøgelsen Helende arkitektur fra Aalborg Universitet og Statens Byggeforskningsinstitut. (Hansen og Permin 27)

Spørgsmålet er imidlertid, om der er tale om en genopdagelse af tidligere tiders viden og erfaring, eller om det ikke snarere drejer sig om en genformulering, der bygger på en anderledes opfattelse af omgivelsernes betydning for sundhed. I denne artikel vil vi argumentere for, at der en afgørende forskel mellem de to historiske former for medikalisering, og at denne 
157 RUNA JOHANNESEN \& ISAK WINKEL HOLM VI BYGGER FOR LIVET

forskel skal forstås ud fra modsætningen mellem to slags biopolitik. Michel Foucaults begreb om biopolitik kræver formentlig ikke nogen omfattende præsentation. Som han skriver i Viljen til viden, Seksualitetens historie 1, er der tale om en politik, der ikke formulerer sig juridisk i love, men retter sig mod menneskets liv, mod bios. Med biopolitik i Foucaults forstand organiseres magt over liv ved hjælp af teknologier til disciplinering af kroppe og regulering af befolkningen (Foucault 139-40).

Biopolitikkens genstand er altså det biologiske liv, men spørgsmålet er, hvad man nærmere skal forstå med dette liv. Denne artikels titel, "Vi bygger for livet," er navnet på Danske Regioners hjemmeside for de mange omfattende hospitalsbyggeprojekter, som blev sat i gang i kølvandet af Strukturreformen i 2007 (Danske Regioner). Vi vil hævde, at det er et andet liv vi bygger for i dag, end dengang Nyrop og Glæsel byggede det første Bispebjerg Hospital. Sat på formel: hvor biopolitikken var somatisk i 1913, er den affektiv i 2021. Dengang havde den medikaliserede hospitalsarkitektur fokus på menneskets kropslige liv, ikke mindst på immunforsvarets kamp mod fremmede organismer såsom bakterier og vira. I dag retter den medikaliserede arkitektur sig snarere mod menneskets affektive liv, og det vil sige mod det sansemæssige møde med omgivelserne. Denne artikels tese er med andre ord, at en grundlæggende historisk forskydning i den kollektive forståelse af forholdet mellem menneskeliv og samfundsliv, mellem bios og polis, har afgørende konsekvenser for udviklingen af hospitalsarkitekturen.

Vores ambition er deskriptiv snarere end kritisk. Den medikalisering af hospitalsarkitekturen, der ofte ses som en genkomst af tidligere tiders viden og æstetiske idealer, betragter vi snarere som en affektiv reformulering af arkitekturens rolle som instrument for helbredelse. Med sondringen mellem somatisk og affektiv biopolitik foreslår vi altså en begrebsliggørelse af en udviklingstendens i moderne hospitalsarkitektur - i første omgang uden at forholde os til, om denne udvikling er ønskværdig eller ej.

For at undersøge modsætningen mellem klassisk og aktuel medikalisering vil vi se nærmere på to aktuelle hospitalsbyggerier, der virkeliggør idealet om en helende arkitektur på henholdsvis en stor og en lille skala. Vores ene case er Nyt Hospital Nordsjælland, der er under opførelse i den kommende bydel Favrholm i Hillerød, og som er tegnet af arkitekterne 
158 KULTUR \& KLASSE *131*2021 SYGDOM

Herzog \& de Meuron og Vilhelm Lauritzen. Vores anden case er "Fremtidens Fødestue" på Hospitalsenheden Vest i Herning, hvor man i et allerede eksisterende hospitalsbyggeri har indrettet en fødestue med en komposition af video, lys, lyd og møbler som tilsammen skaber en hjemlig og tryg atmosfære.

Før vi når til de to cases, må vi imidlertid skitsere henholdsvis den historiske og den teoretiske ramme for vores analyse. Først vil vi give en oversigt over udviklingen fra hospitalsarkitekturen i starten af det forrige århundrede over efterkrigstidens modernistiske "hospitalsmaskiner" og frem til vores dages hospitalsbyggeri. Dernæst vil vi give en kort teoretisk redegørelse for det, vi foreslår at kalde en affektiv biopolitik (i modsætning til en somatisk biopolitik). Og endelig vil vi altså fokusere på hospitalet i Nordsjælland og på fødestuen i Herning.

\section{MEDIKALISERING}

Inden for sociologien har man siden 1970'erne talt om en stigende "medikalisering" af samfundet, forstået på den måde, at medicinsk diagnosticering er kommet til at spille en stadig større rolle som forklaringsmodel for sociale forhold, og at medicinsk retorik og teknologi i stadig højere grad bliver brugt til social kontrol (Illich; Conrad). Inden for arkitekturforskningen er medikalisering imidlertid ikke noget særlig udbredt begreb. Mest iøjnefaldende er det blevet anvendt $i$ antologien Imperfect Health: The Medicalization of Architecture (2012), hvor det fungerer som et samlebegreb for alle former for arkitektur, der baserer sig på ideer om sundhed og medicinsk praksis (Borasi og Zardini). Vi foreslår at bruge begrebet som en betegnelse for det forhold, at arkitekturen bliver opfattet som et remedie for helbredelse, det vil sige som et kurativt instrument.

I et historisk perspektiv begynder medikaliseringen af arkitekturen i slutningen af 1700-tallet (Verderber og Fine; Wagenaar et al.; Meuser). Den svenske filosof Sven-Olov Wallenstein beskriver i Bio-Politics and the Emergence of Modern Architecture (2008), hvordan det klassiske arkitekturparadigme i slutningen af det 18. århundrede blev afløst af et biopolitisk paradigme. Hvor arkitekturen tidligere var en symbolsk form, der repræ- 
senterede samfundets orden, blev den nu et biopolitisk redskab, en "helbredelsesmaskine" (Wallenstein 31), der skulle bruges til at ælte og forme befolkningens biologiske liv:

\begin{abstract}
Arkitekturen mistede sin traditionelle autoritet som symbolsk form, men i denne proces udviklede den sig også til at blive et knudepunkt i det netværk af viden og praksis, der formede individer, og som fik det moderne sociale rum til at opstå. Som vi skal se, fik det, der begyndte som en medikalisering af rummet, hurtigt en mere generel betydning og blev et af de fundamentale træk ved arkitekturens biopolitiske struktur. (14, vores oversættelse)
\end{abstract}

Et vigtigt vendepunkt i udviklingen af den medikaliserede hospitalsarkitektur var opdagelsen af bakterierne i sidste halvdel af 1800-tallet. Inden da havde man været af den opfattelse, at smitsomme sygdomme var forårsaget af såkaldte miasmer, en betegnelse for sygdomskim i dårlig, ildelugtende og fugtig luft, der trænger op fra undergrunden. For at undgå sygdomme, måtte man derfor sørge for at tilføre frisk luft, så den forurenede luft ikke hobede sig op. Selv om miasmeteorien senere viste sig at være fejlagtig, gav de praktiske erfaringer fra de store epidemier, ikke mindst 1800-tallets koleraepidemier, anledning til nye former for byplanlægning med fokus på forbedrede sanitære forhold. Allerede med den britiske sygeplejerske Florence Nightingales anvisninger i Notes on Hospitals (1859) blev man overbevist om, at patienter havde større chancer for at overleve, hvis man byggede hospitaler som pavilloner, der kunne sikre frisk luft, lys og renlighed.

Med opdagelsen af bakterierne kunne denne forestilling om hygiejne belægges videnskabeligt, og det havde vigtige konsekvenser for, hvordan man indrettede ikke blot hospitaler, men også private hjem og hele byer. Uden at bruge begrebet medikalisering undersøger den amerikanske arkitekturhistoriker Beatriz Colomina denne historiske periode i bogen X-Ray Architecture (2019). Colominas overordnede tese er her, at moderniteten var "drevet af sygdom" (Colomina 11, vores oversættelse), forstået på den måde, at det 20. århundredes arkitektur tog form efter de samtidige landvindinger inden for medicinen. Ifølge Colomina var det afgørende ikke mindst lægevidenskabens voldsomme optagethed af tuberkulosen (den tyske læge Robert Koch opdagede tuberkelbacillen i 1882) og af denne sygdoms pri- 
mære diagnostiske instrument, røntgenapparatet (opfundet af den tyske fysiker Wilhelm Röntgen i 1885).

Selvom tuberkelbacillen var blevet opdaget, havde man endnu ikke nogen medicinsk kur mod sygdommen før opdagelsen af streptomycin i 1943, og derfor var det stadig de gamle dyder om lys, luft og hygiejne, der stod ved magt. Men til forskel fra tidligere var fjenden nu blevet identificeret: bakterierne. Alt hvad der kunne være urent og kunne samle de for øjet usynlige bakterier, skulle undgås. Den gamle arkitektur med dens dunkle rum og forsirede ornamenter blev dermed dæmoniseret som sundhedsskadelig. I tuberkulosesanatoriets tid blev arkitekten med andre ord en "bakteriolog", som Colomina skriver, mens arkitekturen blev "bakteriel": "Mikrober var både den bogstavelige og metaforiske basis for en ny arkitektur og urbanisme. [...] Den moderne arkitekturs hvidhed er utvetydigt hospitalets arkitektur" (Colomina 73). Det var altså ikke mindst som stilideal, at medikaliseringen fik afgørende indvirkning på moderne arkitektur: medicinsk tænkning kom til at gennemsyre design med ideer om ventilation, sollys, hygiejne, hvide vægge og kropslig træning.

Fra 1930'erne og frem gjorde den medicinske og teknologiske udvikling imidlertid, at medikaliseringen af hospitalsarkitekturen blev mindre fremtrædende. I denne periode blev hospitalsbyggeriet hovedsageligt forstået som en ramme for den specialiserede terapeutiske praksis, og ikke som en integreret del af denne praksis. Hospitalerne voksede dramatisk i størrelse, og godt hjulpet på vej af de byggeteknologiske fremskridt, der blandt andet muliggjorde multietagestrukturer, blev der udviklet typologier som f.eks. den karakteristiske "matchbox-on-a-muffin" - et sengetårn, der hviler på en flad base bestående af fælles servicefunktioner (Wagenaar). Frem til 1980'erne dominerede denne stil hospitalsbyggeriet i international sammenhæng, og fokus var på effektivitet, funktionalitet, standardisering og repetition. I Danmark er Rigshospitalets Centralkompleks (1970-1974) af Jørgen Stærmose og Kay Boeck-Hansen et godt (og ofte udskældt) eksempel på "matchbox-on-a-muffin"-typologien. Hospitaler fra denne periode omtales ofte som "medicinske maskiner," og med deres utilitaristiske og funktionalistiske tilgang kritiseres de gerne for at være dehumaniserende (Terkildsen; Bates; Wagenaar). 
I de seneste årtier er den medikaliserede hospitalsarkitektur imidlertid vendt tilbage. Vi skal understrege, at vi her ikke taler om bratte skift fra en medikaliseret til en ikke-medikaliseret og tilbage igen til en medikaliseret arkitektur, men derimod om glidende overgange og vægtforskydninger mellem forskellige arkitektoniske opfattelser. Ikke desto mindre er det iøjnefaldende, at det fysiske hospital i dag ikke udelukkende tænkes som en neutral ramme for de avancerede medicinske instrumenter, men i stigende grad også som et terapeutisk instrument i sig selv.

Et afgørende vendepunkt er her den amerikanske sundhedsdesignforsker Roger Ulrich, som i en berømt artikel fra 1984, "View through a Window May Influence Recovery from Surgery", kunne dokumentere, at de fysiske omgivelser havde indvirkning på patienters helbredelse (Ulrich). Ulrich beskæftigede sig oprindeligt med, hvorvidt skønhed, ikke mindst naturskønne scenerier, havde en positiv effekt på menneskets følelsesmæssige velbefindende. I den berømte artikel fra 1984 kunne han konkludere, at post-operative patienter, som han havde observeret, led af færre stress-relaterede komplikationer, krævede mindre doser smertestillende medicin og havde kortere hospitalsophold, hvis de fra vinduet i deres sengestue havde haft udsigt til træer frem for en murstensvæg.

Med Ulrich ser vi med andre ord en interesse for menneskets sansemæssige forhold til omgivelserne. Arkitekturens terapeutiske virkning forskydes fra krop til sansning - fra den somatiske reaktion på indtrængende mikrober til den affektive respons på f.eks. et træ uden for vinduet. Denne forskydning går hånd $\mathrm{i}$ hånd med en ambition om at levere videnskabelig dokumentation for arkitekturens terapeutiske effekt. I kølvandet på Ulrichs studie populariseres og udbredes disciplinen "evidensbaseret design" (EBD), der i analogi til det velkendte begreb om evidensbaseret medicin betegner en praksis, hvor designbeslutninger belægges med videnskabelige fakta etableret gennem empiriske undersøgelser.

Inden for denne tradition er det ikke længere tilstrækkeligt blot at formode, at blandt andet farver, lys, haver og bevægelsesfremmende rum har en positiv effekt på patienternes helbredelse (Ulrich et al.; Verderber et al.; Wagenaar et al.; Kirk Hamilton). For fyrre år siden var udgangspunktet måske nok Ulrichs studier af "skønhed," men ikke desto mindre er der i dag 
tale om en grundlæggende resultatorienteret tilgang til sanseerfaringen, hvor det er det empiriske belæg, ikke den æstetiske dom, der fungerer som argument i designbeslutninger. Det afgørende er ikke længere, hvor smukt hospitalets byggede rum kan siges at være, men hvor godt det virker.

\section{AFFEKTIV BIOPOLITIK}

I Non-Representational Theory (2009) peger den britiske kulturgeograf Nigel Thrift på en form for biopolitik, der ikke handler om befolkningens biologiske liv, men snarere om dens affektive liv. Thrift medgiver, at Michel Foucault og Giorgio Agamben har vist, at biopolitikken befinder sig i centrum af den vestlige verdens magtformer, men han tilføjer, at den mest dominerende form for biopolitik i dag er "det subliminales mikrobiopolitik" (Thrift 192, vores oversættelse). Hermed menes en form for biopolitik, der ikke monitorerer og analyserer menneskets krop, men i stedet retter sig mod menneskets affektive respons på omgivelserne. Dette møde kan kaldes subliminalt, fordi affekterne i høj grad gør deres arbejde neden under bevidsthedens grænse.

Thrifts begreb om mikrobiopolitik er ikke rigtig slået an i det årti, der er gået siden udgivelsen af Non-Representational Theory, måske fordi ordet bringer tankerne hen på mikrobiologi, som ikke har noget med sagen at gøre. Af den grund vil vi tillade os i stedet at sondre mellem somatisk og affektiv biopolitik. Som alle modsætninger mellem kødet og ånden skal modstillingen mellem somatisk og affektiv biopolitik ikke forstås alt for firkantet. Det siger sig selv, at menneskekroppen spiller en vigtig rolle i begge former for biopolitik, for så vidt som affektive reaktioner altid vil rumme en legemlig komponent. Den afgørende forskel ligger i, hvordan kroppen afficeres udefra: om det er gennem fysiologiske processer (som f.eks. indtrængende bakterier) eller gennem perceptive processer (som f.eks. sansningen af et træ uden for hospitalsvinduet).

Interessen for den affektive påvirkning af menneskekroppen har Thrift arvet fra barokfilosoffen Baruch de Spinozas radikale affektteori, og i anden omgang fra spinozisterne Gilles Deleuze og Brian Massumi. Når Spinoza taler om affekter, affectus, drejer det sig ikke om følelser i gængs 
forstand, men derimod om det spil af kræfter, hvormed ting og kroppe i verden afficerer og afficeres af hinanden. Ifølge Massumi og Deleuze går denne grundlæggende skubben og bliven skubbet forud for det enkelte menneskelige subjekt, der kan kigge ind i sig selv og konstatere, at hun føler et eller andet. Når Thrift fra dette teoretiske udgangspunkt taler om affekt og politik, handler det med andre ord ikke om de velkendte følelsers rolle i politik - vreden, entusiasmen, medlidenheden, osv. - men derimod om en form for politik, der retter sig mod den måde, hvorpå mennesker overhovedet bliver sansemæssigt påvirket af deres omgivelser.

I det seneste årti har der været en både velformuleret og velbegrundet kritik af Massumis og Thrifts version af Spinozas affektteori. Det vigtigste kritikpunkt har været, at de med lidt tvivlsomme naturvidenskabelige eksempler argumenterer for en subjektopfattelse, der ensidigt prioriterer menneskets førbevidste og førsproglige side på bekostning af dets sproglige og rationelle side (Leys; Wetherell). Den tyske filosof Jan Slaby giver et morsomt signalement af Massumi som en lifestyle-aktivist eller guru, hvis filosofiske prosa rummer elementer af yogakursus og new age-esoterik (63). Når vi her støtter os til Thrifts affektteoretiske overvejelser, er det imidlertid ikke, fordi vi tilslutter os hans subjektfilosofiske projekt, men derimod fordi vi mener, at hans historiske analyse er øjenåbnende.

Ifølge denne analyse er der i den moderne verden indtruffet en forskydning i forholdet mellem affekt (i den omtalte betydning af ordet) og politik. Affektive teknologier har ganske vist altid spillet en rolle for det politiske. Som eksempel på en virkningsfuld teknologi nævner Thrift de militære træningsprogrammer, der siden 1700-tallet er blevet brugt til at monitorere og analysere, hvordan menneskekroppe reagerer i kampsituationer. Før de amerikanske soldater blev sendt til Vietnam, gennemgik de en grundig eksercits, der gjorde dem i stand til at skyde for at dræbe - og ikke, som de fleste uvægerligt vil gøre, når de står ansigt til ansigt med et andet menneske, at komme til at skyde ved siden af.

Det nye er altså ikke, at der findes affektive teknologier, der laver ingeniørarbejde på menneskekroppens respons på dens omgivelser. Forandringen i forholdet mellem affekt og politik skyldes snarere, at disse affektive teknologier bliver stadig mere udbredte og stadig mere avancerede. Den 
164 KULTUR \& KLASSE *131*2021

SYGDOM

hastigt voksende viden kommer i høj grad fra marketing, der har udviklet en detaljeret indsigt i forbrugerens subliminale impulser i forbindelse med produktvalget, men der kommer også vigtige impulser fra neurovidenskaben, der er blevet i stand til at kortlægge det dunkle halve sekund før sanseindtrykkene bliver forvandlet til bevidsthed. Den affektive respons er med andre ord ikke længere et naturfænomen, men et kulturfænomen: noget, som vi er blevet i stand til at bearbejde og designe.

Som kulturgeograf er Thrift først og fremmest interesseret i moderne byer, som han beskriver som "konditionerende miljøer", i stil med de træningslejre rekrutterne opholdt sig i, før de blev sendt til Vietnam. Vi forventer i stigende grad, at byer skal have "buzz" og være "kreative" (172), og det vil sige, at de skal fungere som affektive teknologier, der fremelsker byboernes evne til at opfatte og opfinde ting. I storbyen er affekt altså ikke bare et individuelt og psykologisk fænomen; der er først og fremmest et kollektivt affektivt arrangement, der skal forstås som en vigtig del af byens infrastruktur: "affekt bliver stadig mere hyppigt gjort til genstand for et aktivt ingeniørarbejde, med det resultat, at den kommer til at minde mere om det netværk af rør og ledninger, der er så vigtige, fordi det leverer det urbane livs grundlæggende mekanik og basale tekstur" (172). Affektpolitikken (eller "mikrobiopolitikken") kan med Thrift beskrives som en ny form for landskabsarkitektur, der ikke kun designer menneskets fysiske, men også dets følelsesmæssige omgivelser (187). Som vi skal se i de cases, som vi fokuserer på i de næste afsnit, spiller denne affektive landskabsarkitektur en afgørende rolle i det aktuelle danske hospitalsbyggeri.

\section{MERE END AT VÆRE I LIVE}

Nyt Hospital Nordsjælland uden for Hillerød er et barmarksprojekt, hvis ambition er at skabe en helt ny hospitalstypologi. Med et helhedsligt arkitektonisk greb forsøger arkitekterne Herzog \& de Meuron og Vilhelm Lauritzen Arkitekter at give en ny tids idéer om hospitalets funktion og organisation en konkret rumlig form: en cirkel, der med fire bløde tryk udefra er kommet til at ligne et firkløver. Herved adskiller Nyt Hospital Nordsjælland sig fra de øvrige aktuelle hospitalsbyggerier, eksempelvis Nyt 
165 RUNA JOHANNESEN \& ISAK WINKEL HOLM VI BYGGER FOR LIVET

Hospital Nordjylland i Gødstrup og Det Nye Universitetshospital i Aalborg, der begge er formet som "byer" af bygninger bundet sammen af en intern infrastruktur, ikke ulig et moderne universitetscampus. Bygningerne i sig selv ligner til forveksling generiske domiciler.

I konkurrenceprogrammet til Nyt Hospital Nordsjælland opstilles medikaliseringen af arkitekturen som et krav til det kommende byggeri:

[D]er er således allerede mange erfaringer om, at det, man som begreb betegner helende arkitektur, har en dokumenteret effekt. Dette projekt skal forholde sig til disse erfaringer, men også lægge op til, at nye løsninger kan afprøves, og eksisterende løsninger kan gentænkes, så funktioner optimeres inden for de givne forudsætninger i en visionær og gennemtænkt hospitalsarkitektur. (Nyt Hospital Nordsjælland This is it - your blank canvas 104)

I bygherrens materiale om vinderprojektet bliver ambitionen om at skabe helende arkitektur en bærende tanke: det er afgørende, "at arkitekturen løser vores kliniske behov og understøtter vores dagligdag på hospitalet" (Nyt Hospital Nordsjælland Livskraft 64). Denne ambition om at løse kliniske behov med arkitekturen er knyttet til det tilbagevendende ord "livskraft": "I vores projekt er Livskraft overliggeren og retningen for hvordan, vi skal udvikle organisationen på det nye Nordsjællands Hospital," hedder det programmatisk i hospitalsorganisationens detaljerede og lettere eksalterede magasin fra 2019, der ligefrem bærer titlen Livskraft (Nyt Hospital Nordsjælland Livskraft 98).

"Livskraft" er også navnet på hele organisationsudviklingsprojektet og på den tilhørende hjemmeside, hvor hospitalsdirektør Bente Ourø Rørth forklarer, hvorfor byggeprojektet har fået dette navn: "Det har vi valgt, fordi vi skal være livskraften i Nordsjælland. Vi bygger ikke bare et nyt hospital, men nyfortolker også hospitalets form og funktion i samfundet, og det skal navnet signalere" (Nordsjællands Hospital). Ligesom alle andre hospitaler fra de seneste hundrede år er Nyt Hospital Nordsjælland altså en biopolitisk institution, der hviler på en forestilling om menneskets liv, om bios. Men der er tydeligvis forskel på "liv" og "livskraft", for som hospitalsdirektøren siger i citatet ovenfor, skal ordet "livskraft" signalere en nyfortolkning af hospitalets form og funktion i samfundet. Det er denne nyfortolkning, der interesserer os. 
166 KULTUR \& KLASSE *131*2021

SYGDOM

Ligesom på det gamle og det nye Bispebjerg Hospital er det ikke mindst havearkitekturen, der skal bidrage til at løse de kliniske behov. Under en illustration af det fremtidige hospital, hvor vi ser afslappede mennesker, der promenerer mellem træer og græsplæner inde i centrum af hospitalets bulede cirkelstruktur, lyder billedteksten:

Det har længe været kendt, at udsigt til natur har en beroligende og smertereducerende effekt. På det nye Nordsjællands Hospital vil der være udsyn til naturen samt lys fra det omkringliggende landskab og de mange gårdhaver. Målet er, at bygning og natur smelter sammen. Naturen skal give ro og mulighed for restitution, så patienterne kommer sig hurtigere. Samtidig er det vigtigt, at omgivelserne stimulerer til nysgerrighed og bevægelse. (Livskraft 40)

Ordet "samtidig" i citatets sidste sætning afslører en spænding i magasinets forståelse af naturens terapeutiske virkning. Naturen skal give ro, men samtidig bevægelse; den skal skabe mulighed for restitution, men samtidig stimulere til nysgerrighed. Det fremgår tydeligt, at denne spænding er historisk: det har længe været kendt, at udsigt til natur har en beroligende og smertereducerende effekt, men det er tydeligvis ikke kun denne velkendte effekt, som projektet ønsker at frembringe.

For at forstå denne spænding vil vi se nærmere på magasinets fundamentale, men også ret fluffy forestilling om "livskraft". Umiddelbart kunne det se ud, som om det ikke var andet end et tomt plusord, som magasinet pepper op ved at koble det med andre plusord i en lang række af prædikationer: "Livskraft er en kultur," "Livskraft er tryghed," "Livskraft er nu," "Livskraft er en konstant stræben," "Livskraft er at turde," osv. (Livskraft 101). Det kan være lidt svært at forholde sig til, men vi vil hævde, at den retoriske forestilling om "livskraft" faktisk indebærer en vigtig genformulering af biopolitikkens bærende idé om liv. Det er ikke bare tomme talemåder, når hospitalsdirektøren siger, at ordet kan signalere en nyfortolkning af hospitalets form og funktion i samfundet, eller når magasinet med en af de mange positivt klingende prædikationer siger: "Livskraft gentænker velfærd" (Livskraft 12).

Som det hedder i magasinet, skal hospitalsbyggeriet netop fungere som et bevis på, at der er en afgørende forskel mellem "liv" og "livskraft": "Det nye hospital i Nordsjælland og Favrholm er en enestående mulighed 


\section{RUNA JOHANNESEN \& ISAK WINKEL HOLM}

VI BYGGER FOR LIVET

for at bevise, at livet handler om mere end at være i live; at være aktiv, kreativ og en del af fællesskaber er vitale ingredienser i et godt og sundt liv" (Livskraft 48). Livskraftens mere end det blotte liv skal åbenbart forstås som aktivitet, kreativitet og socialitet.

Når den medikaliserede hospitalsarkitektur skal løse kliniske behov, skal den altså ikke bare gøre det ved at støtte op om menneskets fysiologiske liv, men også ved at stimulere til et vitalt mere.

Det er tydeligt, at denne biopolitiske merværdi skal skabes ved at designe patienternes, de pårørendes og de ansattes affektive interaktion med omgivelserne. Det formuleres allerede i prologen til Livskraft-magasinet: "Det er ideen med Livskraft. Et hospital, der vil være mere end et hospital. I følelsen og oplevelsen hos de besøgende" (Livskraft 13). Når livet er mere end at være i live, og når hospitalet er mere end bare et hospital, "mere end mursten" (titlen på magasinets kapitel 2), har det noget at gøre med følelsen og oplevelsen hos de mennesker, der kommer til at bevæge sig gennem bygningsværket. Gennem hele magasinet omtales denne sanseerfaring som "den bedst mulige personlige brugeroplevelse" og "den bedste serviceoplevelse" (Livskraft 32, 94).

Hvor "liv" i traditionel biopolitisk forstand drejer sig om menneskekroppens restitution, og ikke mindst om immunsystemets muligheder for at nedkæmpe indtrængende organismer, handler "livskraft" altså snarere om menneskets sansemæssige interface med omgivelserne. I magasinets prolog bliver dette interface beskrevet som et spørgsmål om tilpasning:

En organismes Livskraft handler om, hvor godt den tilpasser sig sine omgivelser, eller hvor godt den kan udnytte dem. I dagligdagen siger ordet måske mere om, hvordan vi har det. Om vores velfærd, psykisk og socialt, ligesom ordet omfatter de kropslige, mentale og følelsesmæssige sider af vores liv. (Livskraft 13)

Biopolitikkens fokus er her det affektive liv, forstået som den tilpasning til og interaktion med omgivelserne, hvor mennesket bliver skubbet til af sine sanseindtryk, men også selv skubber tilbage. Med Thrifts begreber kan Nyt Hospital Nordsjælland beskrives som en ny form for landskabsarkitektur, en avanceret affektiv teknologi, der har til opgave at lave ingeniørarbejde på menneskets affektive interface med omgivelserne. 


\section{ET SANSEMÆSSIGT VEDROP}

"Fremtidens Fødestue" er et eksperimentelt projekt på Hospitalsenhed Vest i Herning. I 2014 fik en gruppe jordmødre en idé om at gentænke fødestuens fysiske rum og at skabe en tryg og hjemlig atmosfære på fødegangen. Ifølge jordmødrene virkede den klassiske kliniske hospitalsfødestue kontraproduktivt for en "god fødeproces" (Godtsygehusbyggeri.dk). Med indspil fra eksperter inden for en række faglige discipliner - heriblandt feng shui, designpsykologi og dyrepasning - og med henvisning til den eksisterende forskning i helende arkitektur indrettede de fødestuen som en multisensorisk installation med videoer, der projiceres op på væggene, belysning, hvis farvetemperatur lader sig regulere, lydanlæg og særligt udvalgte møbler. Ud over at være multisensorisk er fødestuen i Herning også interaktiv. De fødende inviteres til selv at justere deres omgivelser ved at vælge billeder og lyde på en iPad, og på den måde bliver sanseoplevelsen tilpasset det enkelte individ eller det enkelte par.

Formålet med denne installation er at få de fødende til at føle sig trygge, så kvinden stimuleres til en øget naturlig produktion af det ve-fremmende hormon oxytocin, hvilket igen hjælper fødslen på vej. Som jordmødrene formulerer det $i$ et interview, er deres forventning, at rummet vil virke positivt ind på den fødendes trivsel og på fødslernes længde (Skouboe, "Fremtidens Fødestue").

Denne forventning er aktuelt ved at blive dokumenteret i det randomiserede kliniske studie "Fremtidens Fødestue" (Lorentzen et al.), men resultaterne fra dette studie er endnu ikke tilgængelige. I den publicerede "study protocol" opstilles det som en præmis, at oxytocin-produktionen kan forstyrres af miljøer, der er præget af teknologi og medicinske indgreb, mens natur, der bringes ind i rummet, er stressreducerende (Lorentzen et al. 1). På Hillerød Hospital, hvor man siden 2014 har testet tilsvarende principper i de såkaldte "sansefødestuer", viser kliniske studier da også, at behovet for kejsersnit kan reduceres, hvis man føder i et rum med dulmende lys, slørede og rolige billedprojektioner og en behagelig lydside (Wrønding et al.).

Ifølge en case-beskrivelse af fødestuen, som man kan finde på hjemmesiden for Godt Sygehusbyggeri, fremstår rummet som "alt andet end 
en operationsstue" (Godtsygehusbyggeri.dk). Som det bliver sagt hele ti gange i denne tekst, skal fødestuen skabe et hjemligt miljø. Den lidt svævende idé om det hjemlige associeres med tryghed, mens synlig teknologi og medicinske instrumenter siges at virke kontraproduktivt på den gode fødeproces. Derudover fremhæves tilstedeværelsen af natur som en positiv affektiv agent. Den produktive atmosfære i fødestuen designes således som en hybrid blanding af hjem og natur: som et helhedsligt miljø af naturbilleder, yndlingsmusik og dagligstuemøbler.

Den anonyme artikelforfatter fortsætter med at beskrive projektets mange kvaliteter:

Hernings multimediebestykkede føde- og sengestuer løfter begrebet 'helende arkitektur' op i tredje potens, skaber en helt uset oplevelse af hjemlighed i et hospitalsmiljø - og giver et kvalificeret bud på den patient 'empowerment', der kunne give kød og blod til alle de flotte ord om patientens meddeltagelse og -ansvar for egen heling. Det er samtidig et konsekvent svar på den evidens om omgivelsernes betydning for helse og heling, der efterhånden hober sig op. (Godtsygehusbyggeri.dk)

At sige at omgivelserne har betydning for helse og heling er med denne artikels begreber at sige, at omgivelserne er medikaliserede. Fødestuens sansemæssige installation skal med andre ord forstås som et "konsekvent" svar på ambitionen om at skabe helende arkitektur. Det afgørende er imidlertid, at denne medikalisering retter sig mod den fødendes sansemæssige oplevelse snarere end mod hendes krop. Ligesom på Nyt Hospital Nordsjælland er det biopolitiske projekt at optimere menneskets affektive interface med omgivelserne. I "Fremtidens Fødestue" er sanseoplevelsen delvis kontrolleret af den fødende selv, som altså har indflydelse på sin egen krops reaktion. Den interaktive fødestue er således en affektiv teknologi: et sansemæssigt vedrop, der erstatter indsprøjtningen af den syntetiske oxytocin, der ellers normalt gives til den fødende med for svage veer.

Som vi har set, er haverne på Nyt Hospital Nordsjælland og det nye Bispebjerg Hospital eksempler på affektiv landskabsarkitektur, hvis vigtigste byggesten er naturen selv: sollyset, den friske luft og de duftende planter. I modsætning hertil fremmaner "Fremtidens Fødestue" snarere en visuel og auditiv repræsentation af naturen, en syntetisk natur formidlet gennem avanceret teknologi. 
I et interview, som vi har lavet med en af de ledende arkitekter på "Fremtidens Fødestue", Esben Bala Skouboe, beskriver han stuen som en teknologisk komposition, der gestalter den affektive atmosfære. Når arkitektur og interaktiv kunst virker sammen, "bliver rummet meget dynamisk, og man kan begynde at komponere oplevelser" (Skouboe, personligt interview, 25.11.2020). Skouboe fortsætter med at understrege vigtigheden af at designe den fødendes sansemæssige oplevelse:

... men - hold nu kæft - vi kan lave rammen og give værdi for mennesker i de sværeste eller de smukkeste øjeblikke, og vi kan være med til at forme de minder, der bliver skabt i folk resten af deres liv. Jeg kan huske duften, jeg kan huske navnet på den første sygeplejerske, jeg mødte, da vi skulle føde vores første barn, jeg kan huske hvert splitsekund af den oplevelse. Lige nu laver vi rammen for næsten 4.000 fødsler om året i Nordjylland. (Skouboe, "Interview: Den interaktive fødestue")

Skouboe tænker her arkitekturen som et redskab til at forme menneskers affektive reaktioner i det nærværende øjeblik, men også deres minder i fremtiden. Med en let omskrivning af Thrifts formulering om affekten som genstand for "et aktivt ingeniørarbejde" (Thrift 172) kan man sige, at menneskers sanser og minder her er et objekt for et aktivt programmeringsarbejde.

\section{AFRUNDING}

Ambitionen med denne artikel har som sagt været deskriptiv snarere end kritisk. Med sondringen mellem somatisk og affektiv biopolitik har vi peget på en udviklingstendens i moderne hospitalsarkitektur, uden at forholde os kritisk til denne udvikling. Umiddelbart er der meget, der taler for, at det er en god oplevelse at blive indlagt på Nyt Hospital Nordsjælland og at føde et barn på den interaktive fødestue i Herning.

Hvis vi her til slut skulle antyde et kritisk perspektiv på bevægelsen fra somatisk til affektiv biopolitik, kan vi inddrage den aktuelle debat om nedskæringerne på de danske fødegange. I de seneste år har der været en omfattende diskussion af de voldsomme forringelser, der betyder, at jordmødrene arbejder under et ekstremt tidspres, med alvorlige konsekvenser for trygheden og sikkerheden for den eller de fødende. 
Det er et problem, som de multisensoriske fødestuer ikke kan løse. Afstanden til hospitalet, overbelægningen på stuerne og manglen på "varme hænder" er materielle forhold, der vanskeligt kan ændres ved hjælp af dulmende fotos af skovlandskaber, yndlingsmusik og hjemlige loungemøbler. Der findes kort sagt sider af den materielle verden, som subjektet ikke forholder sig umiddelbart til gennem sit sanseapparat.

I den føromtalte case-beskrivelse af Hernings "multimediebestykkede" føde- og sengestuer skriver den anonyme forfatter, at de "giver et kvalificeret bud på den patient 'empowerment', der kunne give kød og blod til alle de flotte ord om patientens meddeltagelse og -ansvar for egen heling." Det er kun delvist sandt. Når de vordende forældre sidder med en iPad i hånden på "Fremtidens Fødestue", er de empowered i den meget begrænsede forstand, der handler om at kunne regulere den sansemæssige stimulering af deres egne individuelle kroppe. Men de har ikke nogen medindflydelse på hospitalets systemiske forhold: hvor travlt jordemoderen har, hvor meget de kan spørge lægen om, hvor længe de kan opholde sig på fødestuen, osv. En tilsvarende kritik kan man rette mod Nyt Nordsjællands Hospitals bærende begreb om livskraft, når det bliver fremstillet som et vidundermiddel, der indeholder en sværm af positive forestillinger: kultur, tryghed, konstant stræben og "at turde". Medikaliseringen af hospitalsarkitekturen er altså ikke bare historisk, den er også ideologisk - nemlig når den er knyttet til meget store forventninger om, hvilke problemer arkitekturens design af det affektive rum er i stand til at løse.

RUNA JohANNESSEn, ph.d., adjunkt ved Institut for Bygningskunst og Teknologi, Det Kongelige Akademi - Arkitektur, Design, Konservering. Er del af forskningsprojektet Spaces of Danish Welfare, der udforsker de rumlige aspekter af danske velfærdssystemer, herunder hospitaler.

ISAK WINKEL HOLM, dr.phil., professor i litteraturvidenskab ved Institut for Kunst- og Kulturvidenskab, Københavns Universitet. Seneste udgivelse Kafka's Stereoscopes: The Political Impact of a Literary Style (2020). Er aktuelt ved at færdiggøre en monografi om affekt og stemning i Søren Kierkegaards forfatterskab. 
172 KULTUR \& KLASSE *131*2021

SYGDOM

\section{BUILDING FOR LIFE}

The Medicalization of Danish Hospital Architecture

This article explores the "medicalization" of contemporary Danish hospital architecture. In the modern age, architecture and spatial design have been mobilized as remedies to further the health of the individual patient and of the population in general. In order to understand the present type of medicalization - as opposed to the early modern and classical modern types - we suggest a distinction between two kinds of biopolitics, in Michel Foucault's sense of this term, respectively a biopolitics of bodies and a biopolitics of feelings. If the original medicalization was a somatic biopolitics, the contemporary medicalization could be described as an affective biopolitics, we claim. We focus on the ongoing boom in the construction of new hospitals in Denmark, discussing as empirical cases a planned hospital in Northern Zealand and a "multisensorial" delivery room in Herning, a Danish provincial town.

\section{KEYWORDS}

DA: Hospitalsarkitektur; arkitekturhistorie; affekt; medikalisering; biopolitik; Nyt Hospital Nordsjælland; Fremtidens Fødestue Herning

EN: Hospital architecture; architectural history; affect; medicalization; biopolitics; New North Zealand Hospital; Delivery Room of the Future Herning

\section{LITTERATUR}

Bates, Victoria. "'Humanizing' Healthcare Environments: Architecture, Art and Design in Modern Hospitals." Design for Health 2.1 (2018): 5-19.

Borasi, Giovanna, og Mirko Zardini(red.). Imperfect Health: The Medicalization of Architecture. Zurich: Lars Müller Publisher, 2012.

Colomina, Beatriz. X-Ray Architecture. Zürich: Lars Müller Publishers, 2019.

Conrad, Peter. The Medicalization of Society: On the Transformation of Human Conditions into Treatable Disorders. Baltimore, Md.; London: Johns Hopkins University Press, 2007.

Danske Regioner. "Vi bygger for livet." Web. 31. januar 2021. <https://vibyggerforlivet.dk>

Foucault, Michel. The History of Sexuality: An Introduction. New York: Pantheon Books, 1978.

Godtsygehusbyggeri.dk. "Erfaringscase: Fremtidens sengestuer fødes i Herning." Web. 3. januar 2021. 


\section{RUNA JOHANNESEN \& ISAK WINKEL HOLM VI BYGGER FOR LIVET}

Hansen, Søren Høgh, og Henrik Permin. Bispebjerg Hospital 100 år. Mosaikker afet hospitals liv. København: Bispebjerg og Frederiksberg Hospitaler, 2013.

Illich, Ivan. Limits to Medicine: Medical Nemesis. The Expropriation of Health. London: Marion Boyars, 1976.

Kirk Hamilton, D. "Evidence-Based Practice: Four Levels Revisited." HERD 133 (2020): 26-29.

Leys, Ruth. "The Turn to Affect: A Critique." Critical Inquiry 373 (2011): 434-72.

Lorentzen, Iben; Charlotte Sander Andersen; Henriette Svenstrup Jensen; Ann Fogsgaard; Maralyn Foureur; Finn Friis Lauszus og Ellen Aaagaard Nohr. "Study protocol for a randomised trial evaluating the effect of a "birth environment room" versus a standard labour room on birth outcomes and the birth experience." Contemporary Clinical Trials Communications 14 (2019): 100336.

Meuser, Philipp (red.). Construction and Design Manual: Hospitals and Medical Facilities. Berlin: DOM Publisher, 2019.

Nordsjællands Hospital. "Hvorfor navnet Livskraft?". Web. 31. januar 2021. < www.nordsjaellandshospital.dk/om-hospitalet/livskraft-organisationsudviklingsprojekt/ vision/Sider/Hvorfor-navnet-Livskraft.aspx >

Nyt Hospital Bispebjerg. Web. 16. september 2020. <https://www.bispebjerghospital.dk/ nythospital/nyt-og-presse/nyheder/2018/Sider/Milliondonation-skal-give-nytliv-til-de-fredede-haver-på-Bispebjerg-Hospital.aspx.>

Nyt Hospital Nordsjælland. Livskraft. Ed. Programkontoret og Direktionen, Nordsjællands Hospital, Region Hovedstaden. 2019. Web. 16. september $2020<$ https://www. regionh.dk/nythospitalnordsjaelland/til-pressen/Documents/LIVSKRAFT.pdf >

Nyt Hospital Nordsjælland. This is it - your blank canvas. 2020. Web. 16. september $2020<$ https://www.regionh.dk/nythospitalnordsjaelland/english/Press/Sider/ The-competition.aspx $>$.

Polyform Arkitekter. Gardens of Life: Visions- og helhedsplan for Bispebjerg Hospital. 2015. Web. 16. september 2020. <https://www.bispebjerghospital.dk/om-hospitalet/oplev/Documents/Gardens\%20of\%2OLife\%2Opå\%20Bispebjerg\%20Hospital.pdf〉 .

Skouboe, Esben Bala. "Fremtidens Fødestue." Lys 272 (2015): 18-19.

Slaby, Jan. "Drei Haltungen der Affect Studies." Stimmungen und Atmosphären. Zur Affektivität des Sozialen. Red. Larissa Pfaller og Basil Wiesse. Wiesbaden: Springer VS, 2018. 53-81.

Terkildsen, Pernille Weiss (red.). Sundhedsarkitekturens ABC. København: ArchiMed A/S, 2015.

Thrift, Nigel. Non-Representational Theory: Space, Politics, Affect. London og New York: Routledge, 2008.

Ulrich, Roger. "View through a Window May Influence Recovery from Surgery." Science 224.4647 (1984): 420-1.

Ulrich, Roger; Craig Zimring; Xuemei Zhu; Jennifer DuBose; Hyun-Bo Seo; Young-Seon Choi; Xiaobo Quan og Anjali Joseph. "A Review of the Research Literature on EvidenceBased Healthcare Design " Health Environments Research \& Design 13 (2008): 61-125. 
174 KULTUR \& KLASSE *131*2021 SYGDOM

Verderber, Stephen og David J. Fine. Healthcare Architecture in an Era of Radical Transformation. New Haven og London: Yale University Press, 2000.

Verderber, Stephen; Shan Jiang; George Hughes og Yanwen Xiao. "The evolving role of evidence-based research in healthcare facility design competitions." Frontiers of Architectural Research 3 (2014): 238-49.

Wagenaar, Cor. "Modern Hospitals and Cultural Heritage." DO.CO.MO.MO JOURNAL Cure and Care, 621 (2020): 36-43.

Wagenaar, Cor; Noor Mens; Guru Manja; Colette Niemeijer; Tom Guthknecht; Giuseppe Lacanna og Peter Luscuere (red.). Hospitals: A Design Manual. Basel: Birkhäuser, 2018.

Wallenstein, Sven-Olov. Biopolitics and the Emergence of Modern Architecture. New York: Princeton Architectural Press, 2009.

Wetherell, Margaret. Affect and Emotion: A New Social Science Understanding. London: SAGE Publications, 2012.

Wrønding, Tine; Aikaterini Argyraki; Jesper Friis Petersen; Märta Fink Topsøe; Paul Michael Petersen og Ellen C.L. Løkkegaard. "The aesthetic nature of the birthing room environment may alter the need for obstetrical interventions - an observational retrospective cohort study." Nature; Scientific Reports 9303 (2019): 1-7. 